\title{
THE CONCEPT OF MASLAHAH IN ISLAMIC FINANCIAL LITERACY AMONG YOUTH IN BANK NEGARA MALAYSIA MUSEUM ART AND GALLERY
}

\author{
Mohd Halim Mahphoth ${ }^{1}$, Zuraidah Sulaiman ${ }^{2}$ \\ ${ }^{1}$ Faculty of Business and Management, Universiti Teknologi MARA Cawangan \\ Melaka, Malaysian ${ }^{2}$ Azman Hashim International Business School, Universiti \\ Teknologi Malaysia, Malaysia. \\ Email:mohdhalim282@uitm.edu.my
}

\section{Abstract}

The effort to enhance financial literacy has become extremely important and is complementary to the initiative by Consumer Credit Act in order to strengthen the credit consumer protection framework in Malaysia. Therefore, Bank Negara Malaysia Museum Art and Gallery (BNM MAG) educates the public through exhibits that foster visitors' understanding of financial knowledge especially the Sharia compliant matters at their Islamic Finance Gallery. This study examined the relationships between satisfying experiences and generic learning outcomes of youth visitors at BNM MAG. The study examined three key satisfying experiences that had significant and positive effects on the generic learning outcomes of youth visitors including affective, cognitive and sensory experiences. However, social experiences were not significant towards generic learning outcomes on youth visitors. This study provides insights and drive efforts to promote effective delivery of financial education initiatives to Malaysians in a sustainable manner. The authors expect that policymakers or museum managers could make use of the findings to improve Malaysians' financial literacy in general, thus helping Malaysians making informed financial decisions. The study contributes to the advancement of Islamic financial education for the youth with the purpose of improving creative and productive attitudes.

Upaya meningkatkan literasi keuangan menjadi sangat krusial dan mendukung inisiasi Undang-Undang Kredit Konsumen untuk memperkuatkerangkaperlindungan 
kredit konsumen di Malaysia. Maka, Bank Negara Malaysia Museum Art and Gallery (BNM MAG) mengedukasi masyarakat melaluipameran yang memberikan pemahaman kepada pengunjung tentang keuangan khususnya yang berhubungan dengan syariah di Islamic Finance Gallery (Galeri Keuangan Syariah). Studi ini mengkaji hubungan antara kepuasan pengalaman dan hasil pembelajaran umum (generic learning outcomes/GLO) yang dialami pengunjung muda di BNM-MAG. Ada acuan kepuasan pengalaman yang dijadikan objek studi yang memiliki efek signifikan dan positif terhadap GLO di kalangan pengunjung muda termasuk pengalaman afektif, kognitif, dan sensori. Meskipun begitu, pengalaman sosial para pengunjung tidak signifikan terhadap GLO. Studi ini memberi wawasan dan mengenalkan usaha untuk mengenalkan penyampaian yang efektif tentang inisiasi pendidikan keuangan pada warga Malaysia dengan cara yang berkelanjutan. Penulis berharap agar pembuat kebijakan atau pengolah museum dapat memanfaatkan temuan ini untuk meningkatkan literasi keuangan warga Malaysia secara umum, dengan demikian membantu mereka untuk membuat keputusan keuangan yang tepat. Penelitian ini memiliki kontribusi meningkatkan pendidikan keuangan Islam bagi para pemuda dengan tujuan menumbubkan sikap kreatif dan produktif.

Keywords: generic learning outcomes, Islamic finance gallery, museum, satisfying experiences.

\section{Introduction}

Recently, one of the most important announcements from Budget 2021 is the formulation of a Consumer Credit Act aimed at providing a regulatory framework for the issuance of consumer credit and strengthening the supervision of non-bank credit providers. According to Mohamad ${ }^{1}$, around 84,805 Malaysians were declared bankrupt in between 2015 and 2019. Furthermore, he highlighted based on the figure provided by the Insolvency Department, people below the age of 34 made up 26 percent of the bankruptcy cases. Therefore, financial education is a crucial element of creating citizens who will make a positive contribution to the world around them. However, financial education is more than just being aware of saving strategies. According to Pereira and Coelho's students need to understand the role of money, both at a personal level and within society. This includes appreciating the power, responsibility, benefits and challenges that money can bring, and feeling confident in managing these very different associations. Referring to Setiawati, et. al. ${ }^{3}$, the need for Islamic financial literacy research is

1 Athirah Mohamad. "Financial literacy among youth alarmingly low." . New Straits Times, last modified October 13, 2020, https://www.nst.com.my/opinion/letters/2020/10/631937/financial-literacyamong-youth-alarmingly-low

2 Maria C. Pereira, and Filipe Coelho. "Regulatory focus, money attitudes and financial literacy: Evidence from Portuguese young adults." Journal of Family and Economic Issues (2020): 1-11.

3 Rike Setiawati, Sulaeman Rahman Nidar, Mokhamad Anwar, and Dian Masyita. "Islamic financial literacy: Construct process and validity." Academy of Strategic Management Journal 17, no. 4 (2018):

Jurisdictie: Jurnal Hukum dan Syariah Vol. 11 No.2 Tabun 2020 
driven by the obligation to obey the rules of Islam, internally, and also due to external factors, such as the availability of complex financial instruments. This leads the Muslim community to respond by making financial decisions based on Islamic financial literacy.

Monetary museums and museums with access to a monetary collection are perfectly placed to provide a learning experience that will facilitate this appreciation. They have the unique opportunity to deliver financial education in a historical context ${ }^{4}$, emphasizing the development of money in society, various cultural relationships with money and the role money has played in the creation and destruction of entities. Taking inspiration from the collection in the Bank Negara Malaysia Museum and Art Gallery (BNM MAG) allows themes surrounding money, such as financial planning, economics, foreign currencies and history of money, to be explored. One of the galleries is dedicated for Islamic Finance portraying the exhibits on foundation concept of Islamic commerce and Finance which originated from Middle East. From this, students can develop an understanding that these sharia concepts have actually been experienced and evaluated over centuries.

Contextualized understanding is therefore paramount in developing an appreciation of money and the social impacts it can have, rather than simply gaining an isolated knowledge of the functions of money. This study will further explore the relationship between students' satisfying experience and generic learning outcomes in the context of financial education and the roles that museum exhibitions play in facilitating this relationship.

\section{Contextual Model of Learning}

By reviewing literatures of educational psychology, learning theory, and visitor studies, it is known that there is a significant body of literature pertaining to learning in physical museums and other free-choice learning environments. Falk and Dierking ${ }^{5}$ formulated a framework called the Interactive Experience Model that has been further refined as the Contextual Model of Learning. This learning model consists of 12 critical suites of factors, clustered into the three contexts (i.e. Personal, Physical \& Sociocultural) which individually and collectively influence the meaning-making process of visitors to free-choice learning settings like museums. No one factor is dominant, and the interaction of these factors is

$1-12$.

4 Annamaria Lusardi. "Financial literacy and the need for financial education: evidence and implications." Swiss Journal of Economics and Statistics 155, no. 1 (2019): 1.

5 John H. Falk, and Lynn D. Dierking. "Learning from museums. Walnut Creek." (2000). 
unique to every individual. The twelve suites of factors are:

a. Personal Context

1. Motivation and expectations

2. Prior knowledge and experience

3. Prior interests and beliefs

4. Choice and control

b. Physical Context

1. Advanced organizers

2. Orientation to the physical space

3. Architecture and large-scale environment

4. Design of exhibits and content of labels

5. Subsequent reinforcing events and experiences outside the museum

c. Sociocultural Context

1. Within-group social mediation

2. Facilitated mediation by others

3. Cultural background and upbringing

\section{Satisfying Experiences and Generic Learning Outcomes}

Satisfying experiences in museums have the potential to influence visitors' learning and therefore long-term overall well-being. Pekarik et al. ${ }^{6}$ designed a satisfying experiences framework that includes four types of valuable museum visitor experiences: object, cognitive, introspective, and social experiences. Doering ${ }^{7}$ suggested that museums should design spaces to specifically elicit these four experiences as they produce beneficial outcomes for the visitor ${ }^{8}$. These four types of enjoyable experiences are also dependent on various positive emotions such as experiencing beauty, feeling a sense of connectedness, or recalling memories? The presence of positive emotions within these four satisfying experiences strengthens their impact on visitors' learning.

6 Andrew J. Pekarik, Zahava D. Doering, and David A. Karns. "Exploring satisfying experiences in museums." Curator: The Museum Journal 42, no. 2 (1999): 152-173.

7 Zahava D. Doering. "Strangers, guests, or clients? Visitor experiences in museums." Curator: The Museum Journal 42, no. 2 (1999): 74-87.

8 Jan Packer. "Beyond learning: Exploring visitors' perceptions of the value and benefits of museum experiences." Curator: The Museum Journal 51, no. 1 (2008): 33-54.

9 Ibid. 
Thus, creating a well-managed customer experience gives museums a competitive edge $^{10}$. Asquith ${ }^{11}$ argued that by creating an overall 'experience,' a museum can attract visitors, encourage repeat visitation, and hold visitors' attention in exhibit elements. Ensuring that visitors are having positive social interactions increases the likelihood of positive overall experiences. Additionally, different content has varying intrinsic value to visitors based on their own personal connections and ability to have meaningful experiences ${ }^{12}$. Engaging with an exhibit can create a positive experience and visitors may recall pleasant memories to make sense of an exhibit ${ }^{13}$. Interactive exhibits facilitate hands on experiences ${ }^{14}$ which allow visitors to try new things, be good at something, or participate in a satisfying experience $e^{15}$.

The visitor also called museum experience by Falk and Dierking ${ }^{16}$ that for several years has been both relevant and complex research subject. Given that, one of the main reasons for visiting museums is to discover and acquire new knowledge. ${ }^{17}$ Hence, this study focuses on the visitor's learning experience. In this context, it should be noted that learning in museums is voluntary, free and guided by the visitor's own choices.

Several authors like Gammon ${ }^{18}$ and Hooper-Greenhill et al. ${ }^{19}$ have proposed models which enable the visitor's learning experience to be measured. This work is particularly interested in the GLO (Generic Learning Outcomes) model devised by Hooper-Greenhill et $\mathrm{a}^{20}$. In fact, this model, in accordance with the work presented in (Bationo Tillon, Marchal, and Houlier, 2011), highlights two dimensions which are analytic and sensitive. These dimensions form the visitor

10 Taskin Dirsehan, and Azize Müge Yalçin. "Comparison between holistic museum visitors and utilitarian museum visitors." International Journal of Marketing Studies 3, no. 4 (2011): 78.

11 Rachel Ann Asquith. "Elements of visitor experience that affect visitor satisfaction in US museums." (2012).

12 John A. Veverka. "Tips and Concepts for planning truly "Interpretive" Exhibits." Veverka and Associates (2003).

13 Ana S. Afonso, and John K. Gilbert. "The nature of exhibits about acoustics in science and technology centres." Research in Science Education 38, no. 5 (2008): 633-651.

14 Ibid.

15 Jane McGonigal. “Fiero! Museums as Happiness Pioneers.” Museum (2009): 49-citation_lastpage.

16 Ibid.

17 Jan Packer, and Roy Ballantyne. "Motivational factors and the visitor experience: A comparison of three sites." Curator: The Museum Journal 45, no. 3 (2002): 183-198.

18 Ben Gammon. "Assessing learning in museum environment." A practical guide for museum evaluators (2003).

19 Eilean Hooper-Greenhill. "Measuring learning outcomes in museums, archives and libraries: The Learning Impact Research Project (LIRP).” International Journal of Heritage Studies 10, no. 2 (2004): 151-174.

20 Ibid. 
experience which result from contact with exhibits. GLO was implemented by the UK Ministry of Museums, Libraries and Archives (MLA). Today it is widely used by several UK museums ${ }^{21}$ and was successfully applied by the mediation services of MLA. According to Hooper-Greenhill et al..$^{22}$, GLO model recognizes learning as an experience whose outcomes include increased knowledge and understanding, additional skills, a change in values and attitudes, feelings of amusement, inspiration and creativity, and an incitement to activity and progression.

Since research works in museology by Pekarik, Doering, and Karns ${ }^{23}$, Kotler $^{24}$ and, Packer and Ballantyne ${ }^{25}$ have distinguished several types of visitor experiences, this study focuses on a particular visitor experience which is the learning experience. Indeed, learning experience is considered to be one of the most important postexperiences of museums namely the generic learning outcomes. To best of the authors' knowledge, there is no published study on the investigation of the satisfying experiences and generic learning outcomes in the context of financial literacy in museums. It is despite the fact that some monetary and financial exhibition in museums started to appear in the recent past years which motivated the authors to construct a research framework (Figure 1) as follows:

Satisfying Experiences

Figure 1. Research Framework

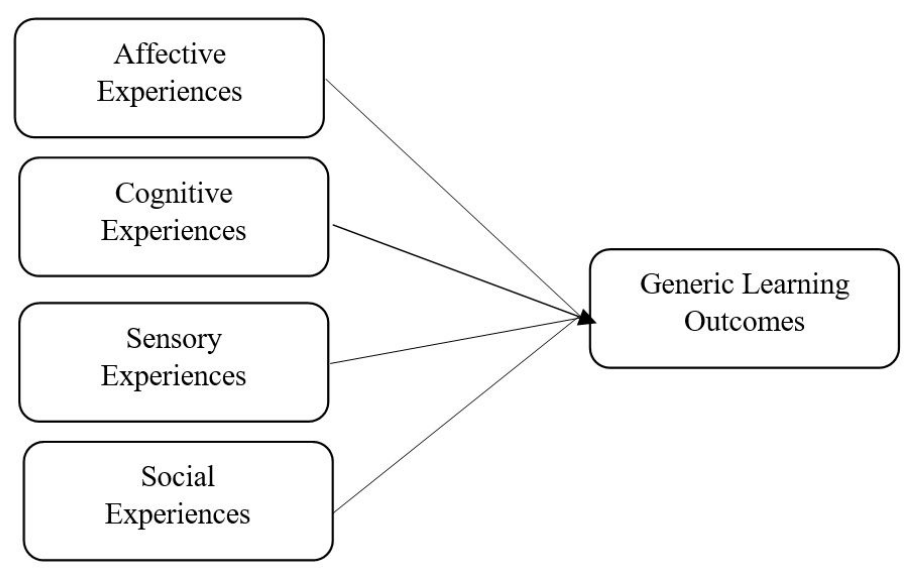

Source: Based on Processed Data

21 Helen Graham, Rhiannon Mason, and Nigel Nayling. "The personal is still political: Museums, participation and copyright." museum and society 11, no. 2 (2013): 105-121.

22 Ibid.

23 Ibid.

24 Ibid.

25 Ibid. 
Therefore, four objectives of this study are; a) investigating the relationship of affective experiences towards generic learning outcomes, b) exploring cognitive experiences towards generic learning outcomes, c) studying sensory experiences towards generic learning outcomes, and d) understanding social experiences towards generic learning outcomes.

Allah states in QS. Al-Israa, 26:

"And give the relative his right, and (also) the poor and the traveler, and do not spend wastefully."

The above verse explains that in Islamic finance, we should concern on wasathon behavior in halalan thoyyiban aspect. It means that, the items purchased or traded is the halal ones (substance or the way obtaining it). Beside fulfilling the needs, in maslahah concept, Islamic finance education for the youth is a habituation on allocating the needs in shabury, hajiy, and tabsiny ways, that is having a social spirit and care for the environment because in Islam, there is other someone else's right in every property we own.

\section{Research Methods}

This section showed the result of data analysis. It is divided into three sections namely demographic profile, reliability analysis, and hypothesis testing. The analysis results indicate the findings on the relationship of satisfying experiences towards generic learning outcomes among students. By running the data through SPSS version 21, mean value of each of variables indicated the response of students on generic learning outcomes. Correlation and multiple regression analysis were used on variables in order to test the proposed hypotheses.

Respondents were sampled from FIN435 (Financial Market and Banking Services) students who participated in a class project during the trip to Bank Negara Malaysia Museum and Art Gallery (BNM MAG). The students' feedback on the survey questionnaire was recorded through Google Form.

\section{Discussion}

From the online survey, 62 students had responded out of 80 questionnaires being distributed, resulted in $77.5 \%$ response rate. From those who responded, all are usable whereby those are completed questionnaire with full feedback. The demographic characteristics of the respondents are shown in Figure 2. 
Figure 2. Gender of Respondents

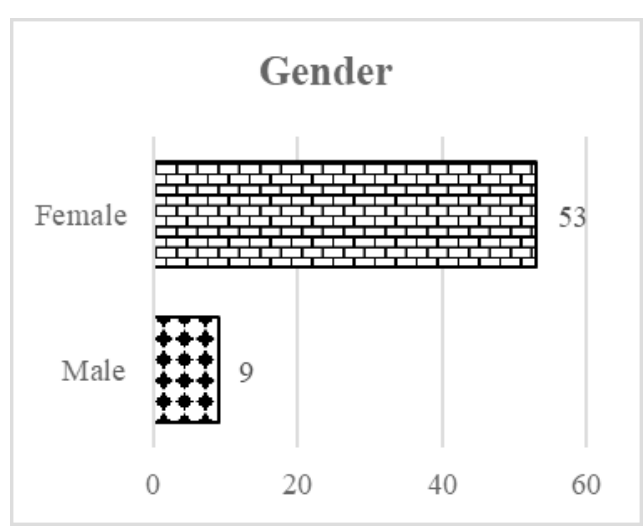

Source: Based on Processed Primary Data

Figure 2 shows gender representation of the student respondents of museum experiences at BNM MAG. Majority of the respondents were females which represented by 53 students or $85.5 \%$ of total respondents, while there were only 9 male students or $14.5 \%$ who had involved in the survey.

\section{Reliability Analysis}

To address reliability, Cronbach's Alphas were calculated for each independent and dependent variable. This test was applied to verify consistency of variables before proceed to further analysis.

Table 1. Reliability Analysis

\begin{tabular}{lc}
\hline \multicolumn{1}{c}{ Variables } & Reliability Coefficient Alpha \\
\hline Independent Variabl & 0.61 \\
Affective experiences & 0.87 \\
Cognitive experiences & 0.80 \\
Sensory experiences & 0.86 \\
Social experiences & \\
Dependent Variable & 0.90 \\
Generic learning outcomes & \\
\hline
\end{tabular}

Source: Based on Processed Primary Data 
As shown in Table 1 , all variables achieved score above 0.6 for their Cronbach's Alpha with the highest-represented by generic learning outcome with 0.9 value, followed by independent variable of cognitive, social and sensory experiences with $0.87,0.86$ and 0.80 respectively. Affective experiences reached the lowest acceptance of Cronbach's Alpha with 0.61 value. In conclusion, all variables above were reliable and proceeded to hypotheses testing.

\section{Hypotheses Testing}

Based on the objectives of this study, two hypotheses were proposed. Each hypothesis was reiterated below and then the result of statistical analysis was reported. All hypotheses were tested by using correlation analysis and multiple linear regression analysis.

\section{Correlation Analysis}

Table 2: Correlation among Satisfying Experiences Determinants and Generic Learning Outcomes

\begin{tabular}{lccccc}
\hline Determinant & $\begin{array}{c}\text { Affective } \\
\text { experiences }\end{array}$ & $\begin{array}{c}\text { Cognitive } \\
\text { experiences }\end{array}$ & $\begin{array}{c}\text { Sensory } \\
\text { experiences }\end{array}$ & $\begin{array}{c}\text { Social } \\
\text { experiences }\end{array}$ & $\begin{array}{c}\text { Generic } \\
\text { Learning } \\
\text { Outcomes }\end{array}$ \\
\hline $\begin{array}{l}\text { Affective } \\
\text { experiences }\end{array}$ & $0.35^{* *}$ & $0.28^{*}$ & 0.06 & $0.42^{* *}$ \\
$\begin{array}{l}\text { Cognitive } \\
\text { experiences }\end{array}$ & $0.35^{* *}$ & & & & \\
$\begin{array}{l}\text { Sensory } \\
\text { experiences }\end{array}$ & $0.28^{*}$ & $0.82^{* *}$ & & $0.63^{* *}$ & $0.72^{* *}$ \\
$\begin{array}{l}\text { Social } \\
\text { experiences }\end{array}$ & 0.06 & $0.63^{* *}$ & $0.54^{* *}$ & & $0.64^{* *}$ \\
$\begin{array}{l}\text { Generic } \\
\text { learning } \\
\text { outcomes }\end{array}$ & $0.42^{* *}$ & $0.72^{* *}$ & $0.69^{* *}$ & $0.42^{* *}$ & $0.42^{* *}$ \\
& & & & & \\
& & & & & \\
\end{tabular}

Source: Based on Processed Primary Data

A correlation coefficient measured the strength of a linear between two variables. In this study, a Pearson correlation coefficient measured the strength of a linear between the generic learning outcomes and four satisfying experiences 
determinants (affective, cognitive, sensory and social). From Table 2, the correlation between overall independent and dependent variables were positive and significant at the 0.01 level (2-tailed), with all values represented in between of 0.42 to 0.72 , which means moderately strong association. The highest association represented by cognitive experiences, the correlation was $0.72(\mathrm{p}=0.000)$ followed by sensory experiences $(\mathrm{r}=0.42, \mathrm{p}=0.000)$. Therefore, the study indicated that there were associations among all substantial experiences determinants and generic learning outcomes.

\section{Multiple Linear Regression Analysis}

Multiple linear regression analysis is a statistical analysis that used to examine relationship between independent and dependent variable. There were two hypotheses tested, namely;

H1: There is significant relationship between affective experiences and generic learning outcomes

H2: There is significant relationship between cognitive experiences and generic learning outcomes

H3: There is significant relationship between sensory experiences and generic learning outcomes

H4: There is significant relationship between social experiences and generic learning outcomes

Table 3. Relationship between Satisfying Experiences Determinants towards Generic Learning Outcomes

\begin{tabular}{lccc}
\hline \multicolumn{1}{c}{ Determinant } & B & Beta & Sig. \\
\hline Affective experiences & 0.15 & 0.19 & $0.044^{*}$ \\
Cognitive experiences & 0.34 & 0.42 & $0.017^{*}$ \\
Sensory experiences & 0.26 & 0.30 & $0.050^{*}$ \\
Social experiences & -0.01 & -0.02 & 0.869 \\
& & & $*$ significant \\
R-Square & 0.58 & & $\mathrm{p}<0.05$ \\
Adjusted R-Square & 0.55 & & \\
Method : Enter & & & \\
\hline
\end{tabular}

Source: Based on Processed Primary Data 
In this standard multiple linear regression analysis, the test relationship of satisfying experiences was applied, which is considered as aggregated variable when acting as independent variables. As a result in Table 3, the independent variables (satisfying experiences determinants) explained $58.0 \%$ of the total variances in the dependent variable (generic learning outcomes) with R-Square 0.58 . Thus, the relationship between all satisfying experiences determinants and generic learning outcomes was strong.

Affective, cognitive and sensory experiences emerged as significant determinant in explaining the satisfying experiences which received p-value of 0.05 reported as positively and significantly related to the dependent variable. For next finding as shown in Table 3, the independent variables (social experiences) received p-value above 0.05 which reported as insignificant. Thus, there was no relationship between social experiences and generic learning outcomes from the study.

Therefore, these findings fail to reject $\mathrm{H} 1, \mathrm{H} 2$ and $\mathrm{H} 3$, meanwhile it rejects $\mathrm{H} 4$ of the study. The findings of this study are not consistent with El-Damshiry and Khali ${ }^{26}$ which affective, cognitive, sensory experiences were the only determinants to foster visitors' learning of financial knowledge in museum. However, this study found that social experience was not considered as one of the satisfying experiences factor towards generic learning outcomes. The previous literature showed different types of satisfying experiences every time they visit the museum. The literature review scenario achieved the main aim of this paper which is to investigate the relationship between satisfying experiences determinants towards generic learning outcomes.

The instrument created for this study can be utilized by other curators and educators in evaluating and understanding their museum visitors within exhibition. They may find this instrument useful in examining the types of visitors' experience whether tally with the significance of the exhibit and the items chosen for display. This study can be used to inform museum practices in multiple ways. For example, satisfying experiences as a construct is related to and therefore, could be reflective of generic learning outcomes. Paying attention to visitors' satisfying experiences in museums is critical in aspects of marketing and membership ${ }^{27}$. Enabling students to experience financial exhibitions in such a broad context will directly contribute to a deeper appreciation of it. This will further enable the outcomes of contextualized financial education sessions to be transferred to every

26 K. K. H. ElDamshiry, and M. H. M. Khalil. "Museum visitors learning identities interrelationships with their experiences.” In Green Heritage Conference: Chance-Change-Challenge, pp. 277-314. Cairo: The British University in Egypt, 2018.

27 Ibid. 
day interactions with financial decisions, creating a more robust and reflective learning experiences. For this reason, it is important to understand the importance of being financially literate and acquire the necessary skills in managing financial resources, especially for youth.

\section{Conclusion}

Maslahah is the most important concept in the development of Islamic economics. This research finds are instrumental for policymakers, educationist, and those involved in developing and administering initiatives geared improving youth financial literacy in every level. The $7^{\text {th }}$ Prime Minister of Malaysia, Tun Dr. Mahathir Mohamad urged that "It is important to increase financial literacy among the people, and the formation of the new consumer credit law will strengthen the protection framework for credit consumers in the country". Thus, the Islamic finance gallery at BNM MAG can encourage initial understanding and ability of Islamic financial literacy of a person from aspects of knowledge, attitudes and behavior of Islamic finance in managing finances based on Sharia principles. Additionally, the findings discovered from this study may also assist the Malaysian government in achieving the aspirations detailed in the National Strategy for Financial Literacy 2019-2023. Thus, the courage of government authorities in making policies and developing sharia-based financial institutions in the country contains a very high malaah value.

\section{References}

Afonso, Ana S., and John K. Gilbert. "The nature of exhibits about acoustics in science and technology centres." Research in Science Education 38, no. 5 (2008): 633651.

Asquith, Rachel Ann. "Elements of visitor experience that affect visitor satisfaction in US museums." (2012).

Dilenschneider, Colleen. “Three-important-reasons-prioritize-visitor-satisfaction-data”. Know Your Own Bone. April 25 (2018).

Dirsehan, Taskin, and Azize Müge Yalçin. "Comparison between holistic museum visitors and utilitarian museum visitors." International Journal of Marketing Studies 3, no. 4 (2011): 78.

Doering,Zahava D. "Strangers, guests, or clients? Visitor experiences in museums." Curator: The Museum Journal 42, no. 2 (1999): 74-87. 
ElDamshiry, K. K. H., and M. H. M. Khalil. "Museum visitors learning identities interrelationships with their experiences." In Green Heritage Conference: Chance-Change-Challenge, pp. 277-314. Cairo: The British University in Egypt, 2018.

Falk, John H., and Lynn D. Dierking. "Learning from museums. Walnut Creek." (2000).

Gammon, Ben. "Assessing learning in museum environment." A practical guide for museum evaluators (2003).

Graham, Helen, Rhiannon Mason, and Nigel Nayling. "The personal is still political: Museums, participation and copyright." museum and society 11, no. 2 (2013): 105-121.

Hooper Greenhill, Eilean. "Measuring learning outcomes in museums, archives and libraries: The Learning Impact Research Project (LIRP)." International Journal of Heritage Studies 10, no. 2 (2004): 151-174.

Jen-Li, Lim. "Malaysia Launches The National Strategy For Financial Literacy. I-Money," Wired, last modified July 23, 2019, https://www.imoney.my/articles/nationalstrategy-financial-literacy

Kotler, Neil. "Delivering experience; Marketing the museum's full range of assets." Museum News 78, no. 3 (1999): 30-+.

McGonigal, Jane. "Fiero! Museums as Happiness Pioneers." Museum (2009): 49citation_lastpage.

Lusardi, Annamaria. "Financial literacy and the need for financial education: evidence and implications." Swiss Journal of Economics and Statistics 155, no. 1 (2019): 1.

Mohamad, Athirah. "Financial literacy amongyouth alarmingly low. New Straits Times." Wired, last modified October 13, 2020, https://www.nst.com.my/opinion/ letters/2020/10/631937/financial-literacy-among-youth-alarmingly-low

Packer, Jan, and Roy Ballantyne. "Motivational factors and the visitor experience: A comparison of three sites." Curator: The Museum Journal 45, no. 3 (2002): 183-198.

Packer,Jan. "Beyond learning: Exploring visitors' perceptions of the value and benefits of museum experiences." Curator: The Museum Journal 51, no. 1 (2008): 33-54. 
Pereira, Maria C., and Filipe Coelho. "Regulatory focus, money attitudes and financial literacy: Evidence from Portuguese young adults." Journal of Family and Economic Issues (2020): 1-11.

Pekarik, Andrew J., Zahava D. Doering, and David A. Karns. "Exploring satisfying experiences in museums." Curator: The Museum Journal 42, no. 2 (1999): 152-173.

Setiawati, Rike, Sulaeman Rahman Nidar, Mokhamad Anwar, and Dian Masyita. "Islamic financial literacy: Construct process and validity." Academy of Strategic Management Journal 17, no. 4 (2018): 1-12.

Tillon, Anne Bationo, Isabelle Marchal, and Pascal Houlier. "Mobile augmented reality in the museum: Can a lace-like technology take you closer to works of art?." In 2011 IEEE International Symposium on Mixed and Augmented Reality-Arts, Media, and Humanities, pp. 41-47. IEEE, 2011.

Veverka,John A. “Tips and Concepts for planning truly “Interpretive" Exhibits." Veverka and Associates (2003). 